\title{
Liposclerosing myxofibrous tumor: a rare tumor of proximal femur
}

\author{
Liposklerozan miksofibröz tümör: Proksimal femurun nadir bir tümörü
}

\author{
Ozan Beytemür, MD., Ümit Seza Tetikkurt, MD., ${ }^{2}$ Cem Albay, MD., ${ }^{3}$ \\ Gonca Kavşut, MD., ${ }^{2}$ Akif Güleç, MD. ${ }^{1}$ \\ 'Department of Orthopedics and Traumatology, Health Sciences University, Bağcılar Training and Research Hospital, İstanbul, Turkey \\ ${ }^{2}$ Department of Pathology, Health Sciences University, Bağcılar Training and Research Hospital, İstanbul, Turkey \\ ${ }^{3}$ Department of Orthopedics and Traumatology, Health Sciences University, Baltalimanı Bone and Joint Diseases \\ Training and Research Hospital, İstanbul, Turkey
}

\begin{abstract}
Liposclerosing myxofibrous tumor is a very rarely observed benign fibro-osseous lesion, which contains complex histological structures. It was first described in the year 1986. Histopathological examination of the lesion may show myxoid areas, osteoclastic activity, bone trabeculae similar to fibrous dysplasia, fat necrosis, ischemic ossification and rarely cartilage components. This lesion, which is particularly localized to the proximal femur, is thought to be associated with fibrous dysplasia. In this case report, we aim to present a liposclerosing myxofibrous tumor case, which was treated surgically, in light of the literature review. The patient who was treated with curettage, grafting and 95-degree dynamic condylar screw-plate system was asymptomatic at the $16^{\text {th }}$ month control and recurrence was not detected.
\end{abstract}

Keywords: Femur; fibrous dysplasia of bone; lipoma; liposclerosing myxofibrous tumor.

Liposclerosing myxofibrous tumor is a very rare benign fibro-osseous lesion. ${ }^{[1-1]}$ It is thought to be associated with fibrous dysplasia because of its clinical, histological and radiological features. This lesion, which is often located in the proximal femur, rarely shows malignant transformation. In this case report, we aim to present a very rare liposclerosing myxofibrous tumor case, which was treated surgically, in light of the literature review.

\section{CASE REPORT}

A 67-year-old male patient admitted to our clinic with a complaint of increasing pain by walking for

\section{$\ddot{O Z Z}$}

Liposklerozan miksofibröz tümör, kompleks histolojik yapılar içeren, çok nadir görülen bir benign fibrooseöz lezyondur. İlk olarak 1986 yılında tanımlandı. Lezyonun histopatolojik incelemesi miksoid alanlar, osteoklastik aktivite, fibröz displazi benzeri kemik trabekülleri, yağ nekrozu, iskemik ossifikasyon ve nadiren kıkırdak komponentleri gösterebilir. Özellikle femur proksimaline yerleşim gösteren bu lezyonun fibröz displazi ile ilişkili olduğu düşünülmektedir. $\mathrm{Bu}$ olgu sunumunda, cerrahi olarak tedavi edilen bir liposklerozan miksofibröz tümör olgusu literatür incelemesi eşliğinde sunuldu. Küretaj, greftleme ve 95 derecelik dinamik kondil vida plak sistemi ile tedavi edilen hasta, 16. ay kontrolünde asemptomatik idi ve nüks saptanmadi.

Anahtar sözcükler: Femur; kemiğin fibröz displazisi; lipom; liposklerozan miksofibröz tümör.

six months in the right hip and thigh. Right hip joint movements were normal at the physical examination. His complaints were increasing particularly with activity. The patient, who had a medical history of surgery due to prostate cancer 15 years before, was under the follow of oncology outpatient clinics. His laboratory findings were normal and prostate specific antigen was $3.03 \mathrm{ng} / \mathrm{mL}$. In the radiological examination; a proximal femoral lesion, starting from right femoral neck and extending to $4 \mathrm{~cm}$ below the minor trochanter, separated by a thin sclerotic line from the surrounding tissue, was detected (Figure 1). At the magnetic resonance imaging

- Received: October 22, 2015 Accepted: January 15, 2016

- Correspondence: Ozan Beytemür, MD. Sağlık Bilimleri Üniversitesi, Bağcılar Eğitim ve Araștırma Hastanesi Ortopedi ve Travmatoloji Kliniği, 34200 Bağcılar, İstanbul, Turkey. Tel: +90 212 - 4404000 / 1131 e-mail: beytemur@yahoo.com 


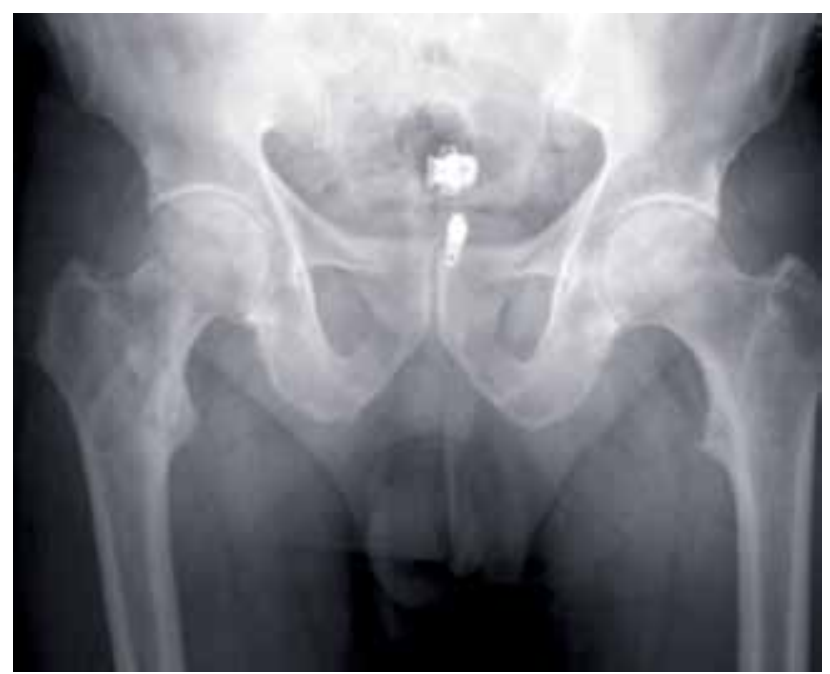

Figure 1. Preoperative direct X-ray view.

examination; a lobulated, $7 \times 3 \mathrm{~cm}$ lesion starting from right femoral neck and extending to femoral diaphysis, separated by a thin sclerotic line from the surrounding tissue, was detected. It was hyperintense on $\mathrm{T}_{2}$-weighted and hypointense on $\mathrm{T}_{1}$-weighted images. The lesion had contrast enchancement in post-contrast series and there were thin septations inside the lesion (Figure 2). At the positron emission tomography-computed tomography examination; increased activity in the prostate, seminal vesicles and right femoral neck was detected. Surgical treatment was planned because of patient's pain complaints and suspected possible bone metastasis.

Firstly, a closed bone biopsy under flouroscopy was performed because lesion was atypical in shape and there was only one bone lesion. On the microscopic examination of the lesion; mixofibrous tissue similar to scattered xanthomatous communities and bone trabeculae similar to fibrous dysplasia were observed. Immunohistochemically, immunoreactivity with smooth muscle actin in the spindle cells of stroma was observed. In light of these findings, the diagnosis of the lesion was reported as liposclerosing myxofibrous tumor (Figures 3, 4).

An intralesional operation was planned. Under general anesthesia, the surgery was initiated with right femur lateral incision on the traction table. After reaching the bone, an oval window was opened. After the entire curettage of the lesion, the walls of the lesion were expanded with the help of high-speed burr. The walls of the lesion were cauterized with $120 \mathrm{~W}$ argon plasma coagulatin till all lesion walls turned to black in color and bone grafting with $90 \mathrm{~mL}$ cancellous allograft was performed. Because of the pathologic fracture risk at the load-bearing region, fixation with a 95-degree dynamic condylar screw (DCS)-plate system was performed. In the pathological examination; liposclerosing myxofibrous tumor was confirmed. Patient was mobilized with crutches on first postoperative day, and he walked by fourth week with full loading. Patient was asymptomatic at the $16^{\text {th }}$ month control and recurrence was not detected (Figure 5). A written informed consent was obtained from the patient.

\section{DISCUSSION}

Liposclerosing myxofibrous tumor was first described by Ragsdale in $1986 .{ }^{[1,5,11]}$ It has a complicated
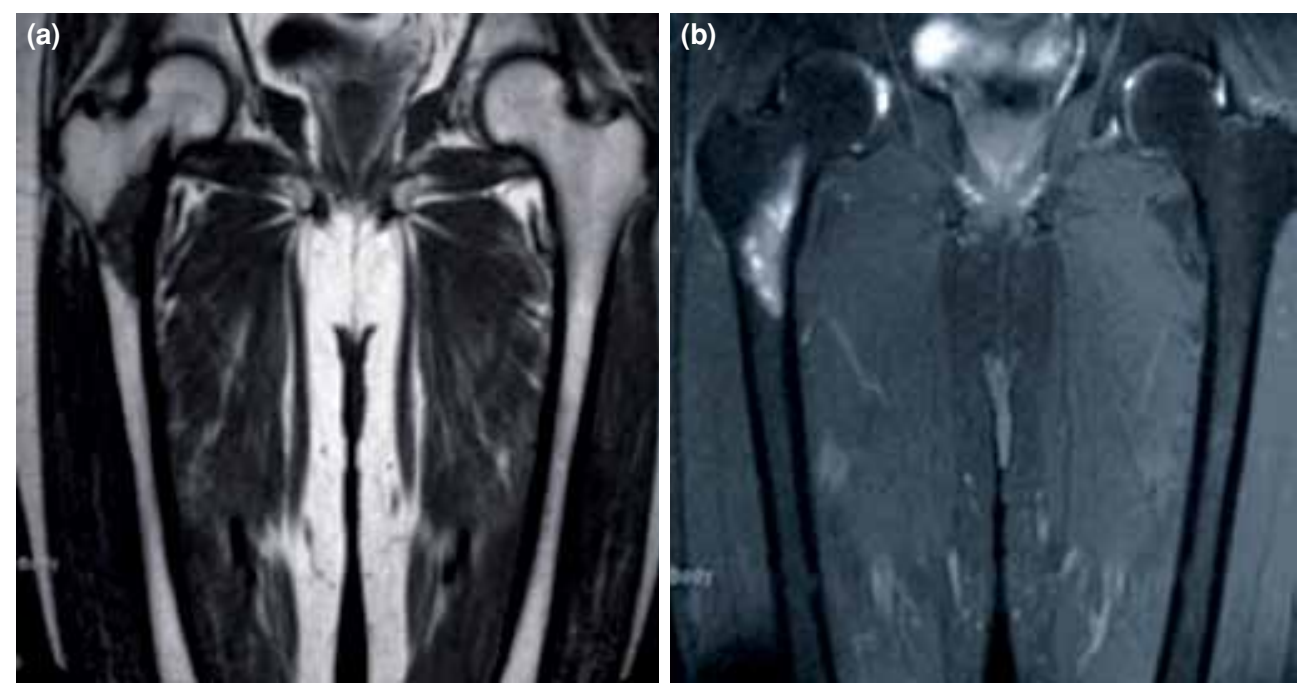

Figure 2. Preoperative magnetic resonance imaging; (a) hypointense lesion on $\mathrm{T}_{1}$-weighted image, (b) hyperintense lesion on $\mathrm{T}_{2}$-weighted image. 


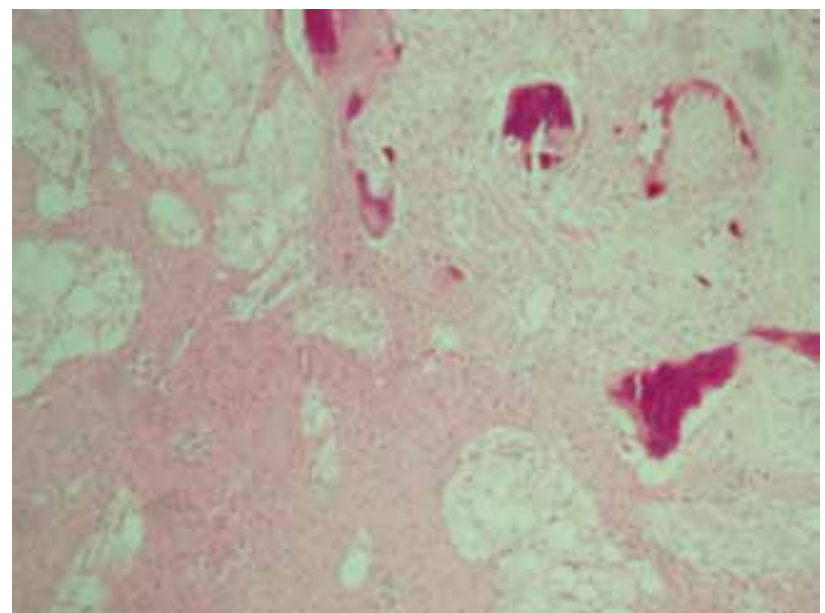

Figure 3. Fibrous tissue separated by fatty tissue and foamy macrophage groups $(\mathrm{H}-\mathrm{E} \times 100)$.

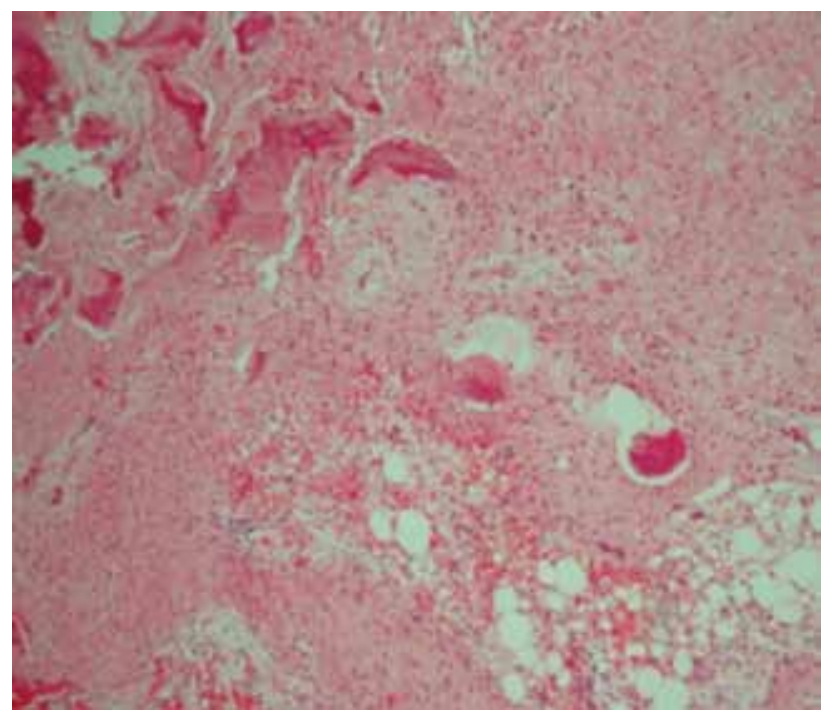

Figure 4. Woven bone trabeculae interspersed in a fibromyxoid background $(\mathrm{H}-\mathrm{E} \times 10)$.

structure, which histopathologically includes myxoid areas, osteoclastic activity, bone trabeculae similar to fibrous dysplasia, fat necrosis, ischemic ossification and rarely cartilage components. ${ }^{[1-3,5,11]}$ The average age of disease occurrence is 40 years. The frequency of males and females is equal. Although a large portion of the proximal femur is affected, other localizations have also been reported, albeit rarely..$^{[1]}$

Radiologically, it is a well-circumscribed lesion surrounded by sclerosis, which shows calcification occasionally. ${ }^{[3,4,9]}$ However, biopsy is required due to being very rare. In the differential diagnosis of our case, due to patient's being 67 years old and having a history of prostate carcinoma, metastatic lesion came

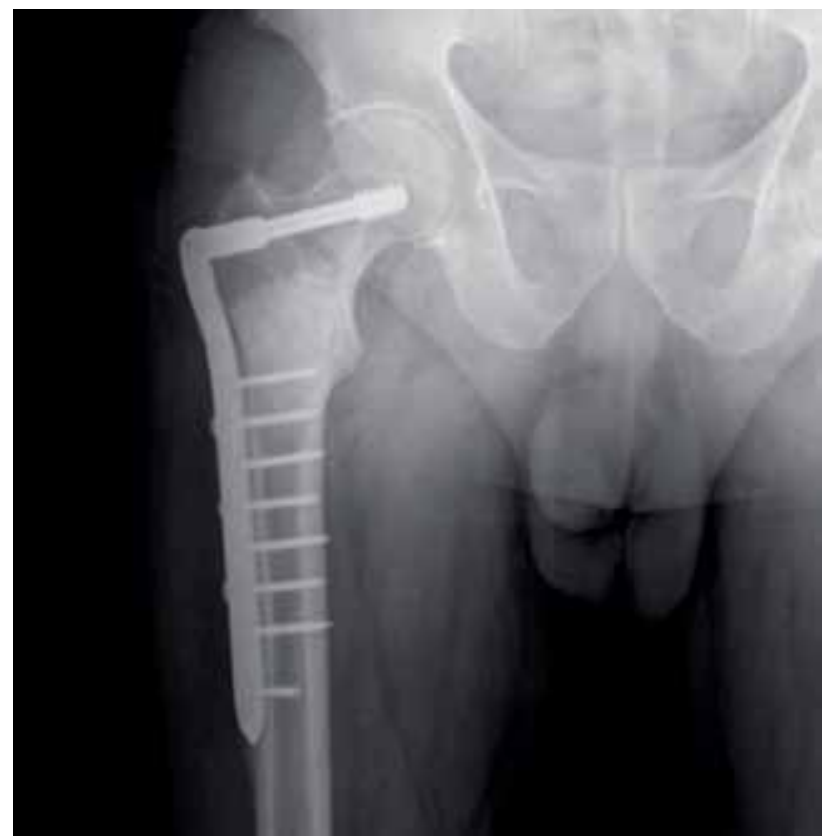

Figure 5. Postoperative direct X-ray view at $16^{\text {th }}$ month control.

to mind. However, failure of definitive diagnosis with radiological assessment, even it is a metastasis, percutaneous Jamshidi needle biopsy was performed since the lesion was solitary. Definitive treatment was planned when the biopsy confirmed the diagnosis.

Liposclerosing myxofibrous tumor has been reported to be associated with fibrous dysplasia because of its radiological and histopathological features. They are intramedullary well-limited lesions just as classic fibrous dysplasia. ${ }^{[12]}$ Indeed, Matsuba et al.$^{[8]}$ detected Gs alpha mutation at Arg201 codon in two cases of liposclerosing myxofibrous tumor. These mutations have also been identified in patients with McCune-Albright syndrome, and monostotic and polyostotic fibrous dysplasia. ${ }^{[6,8]}$

In a study presented by Datillo et al. ${ }^{[13]}$ in 2012, a total of 33 liposclerosing myxofibrous tumor cases were evaluated. Of the 33 cases, histopathologic materials of 18 could be reached. Histopathologically, 12 patients had degenerative form of fibrous dysplasia and three patients had degenerative form of intraosseous lipoma. For this reason, the authors could not establish a diagnosis of liposclerosing myxofibrous tumor. However, the current literature indicates that the diagnosis of liposclerous myxofibroscopic tumor is still considered as a separate lesion. ${ }^{[14-17]}$ We think that due to the presence of myxoid structures composed of fibrous tissue separated by adipose tissue, our case should not be regarded as only intraosseous lipoma or fibrous dysplasia (Figure 3). Thus, we believe that 
liposclerosing myxofibrous tumor should be managed as a separate entity, as indicated in current sources.

Curettage, bone grafting and cementing by intralesional approach are sufficient for treatment due to its being a benign tumor. Yet, malignant transformation has also been reported, albeit very rarely. ${ }^{[2,5,11]}$ In our case, we also applied curettage and grafting with allograft and fixation with 95-degree DCS-plate system. ${ }^{[6]}$ In the surgical treatment, aggressive curettage of the lesion, and use of high-speed burr and adjuvant therapy are important. We routinely prefer to use argon beam cautery as adjuvant therapy in patients with tumors. In case of failure to pay sufficient attention in these steps of treatment, the rate of recurrence increases. ${ }^{[14]}$ We used a 95-degree DCS-plate fixation in order to prevent the risk of fracture at the load carrying area where we opened a bone window. Recurrence was not detected at the $16^{\text {th }}$ month control.

Malignant transformations such as fibrosarcoma, malignant fibrous histiocytoma and telangiectatic osteosarcoma have been reported.$^{[2,5,11]}$ In the literature, a malignant transformation rate of $10 \%$ has been reported..$^{[1,9]}$

In conclusion, liposclerosing myxofibrous tumor should come to mind in the differential diagnosis of heterogeneous, lytic lesions surrounded by sclerosis of proximal femur. Like all other bone tumors, physical examination and evaluation with imaging methods should be performed. If there is any doubt in the diagnosis of the disease, it is very important to implement biopsy before permanent treatment. Because of the risk of malignancy and fracture, surgery should be the preferred treatment. Case series with larger sample size are needed to clarify the relationship with fibrous dysplasia lesions and the progression of the disease.

\section{Declaration of conflicting interests}

The authors declared no conflicts of interest with respect to the authorship and/or publication of this article.

\section{Funding}

The authors received no financial support for the research and/or authorship of this article.

\section{REFERENCES}

1. Ragsdale BD, Sweet DE. Bone. In: Henson E, AlboresSaavedra J, editors. The pathology of incipient neplasia.
Philadelphia: WB Saunders; 1986. p. 381-423.

2. Illac C, Delisle MB, Bonnevialle $\mathrm{P}$, Chiavassa-Gandois $\mathrm{H}$, de Pinieux G, Gomez-Brouchet A. Telangiectatic osteosarcoma secondary to a liposclerosing myxofibrous tumor: a case report. Ann Pathol 2012;32:259-62. [Abstract]

3. Dattilo J, McCarthy EF. Liposclerosing myxofibrous tumor (LSMFT), a study of 33 patients: should it be a distinct entity? Iowa Orthop J 2012;32:35-9.

4. Nieto A, Pérez-Andrés R, Lorenzo JC, Vilanova JC. Diagnostic imaging of liposclerosing myxofibrous tumor of bone. Radiologia 2010;52:251-4. [Abstract]

5. Campbell K, Wodajo F. Case report: two-step malignant transformation of a liposclerosing myxofibrous tumor of bone. Clin Orthop Relat Res 2008;466:2873-7.

6. Corsi A, De Maio F, Ippolito E, Cherman N, Gehron Robey P, Riminucci M, et al. Monostotic fibrous dysplasia of the proximal femur and liposclerosing myxofibrous tumor: which one is which? J Bone Miner Res 2006;21:1955-8.

7. Heim-Hall JM, Williams RP. Liposclerosing myxofibrous tumour: a traumatized variant of fibrous dysplasia? Report of four cases and review of the literature. Histopathology 2004;45:369-76.

8. Matsuba A, Ogose A, Tokunaga K, Kawashima H, Hotta T, Urakawa S, et al. Activating Gs alpha mutation at the Arg201 codon in liposclerosing myxofibrous tumor. Hum Pathol 2003;34:1204-9.

9. Kransdorf MJ, Murphey MD, Sweet DE. Liposclerosing myxofibrous tumor: a radiologic-pathologic-distinct fibro-osseous lesion of bone with a marked predilection for the intertrochanteric region of the femur. Radiology 1999;212:693-8.

10. Gilkey FW. Liposclerosing myxofibrous tumor of bone. Hum Pathol 1993;24:1264.

11. Choi JW, Lee YS, Lee JH, Kim HK, Yeom BW, Choi JS, et al. Liposclerosing myxofibrous tumor in tibia: A case report and review of the literature. The Korean Journal of Pathology 2005;39:207-10.

12. Atik OŞ, Ayanoğlu T, Atalar H, Yörübulut M. One patient, one bone, and two different tumoral lesions. Eklem Hastalik Cerrahisi 2016;27:51-3.

13. Dattilo J, McCarthy EF. Liposclerosing myxofibrous tumor (LSMFT), a study of 33 patients: should it be a distinct entity? Iowa Orthop J 2012;32:35-9.

14. Abraham JA, Cystic and Radiolucent Bone Lesion. In: Biermann JS, editor. Orthopaedic Knowledge Update Musculoskeletal Tumors. Rosemont: American Academy of Orthopaedic Surgeons; 2014. p. 92.

15. Wei S, Siegal GP. Fibrooseous Lesions. Atlas of Bone Pathology. New York: Springer; 2013. p. 203-5.

16. Manaster BJ, David A, Fibrous Tumors an Tumorlike Conditions. Musculuskeleteal Imaging. 4th ed. Philadelphia: Elsevier Saunders; 2013. p. 404.

17. Saupe NM. Extra-articular Conditions. In: Kim Y, Mamisch TC. Hip Magnetic Resonans Imaging. New York: Springer; 2014. p. 188-9. 